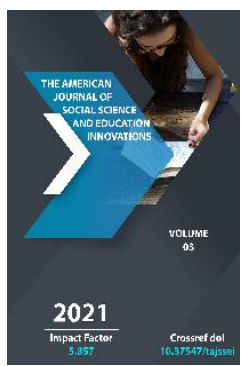

\title{
Factors Affecting The Individual Investigation Of Key Actions In Training Fighting And Competitions
}

Tursunaliev I.A.

Physical Education And Sports Under The Ministry Of Physical Education And Sports Professionals, Scientific And Methodological Support, Training And Skills Development Center In Tashkent, Uzbekistan

Journal Website:

http://usajournalshub.c om/index,php/tajssei

Copyright: Original content from this work may be used under the terms of the creative commons attributes 4.0 licence.

\section{ABSTRACT}

Identify ways for young boxers to achieve high results in combat, which consists of a large number of different movements that are performed very quickly in competitive fights, by determining the degree of correlation between the application of basic movements in training fights and competitions, the scope of application of preparatory movements and the effectiveness of basic movements.

\section{KEYWORDS}

Boxer, attack, defense, training fights, competition preparation, technical-tactical actions .

\section{INTRODUCTION}

Athlete's competitive activities include competitive actions and actions in the process of competition that combine their complex forms . In many sports, the focus is on individual competitive actions, while in boxing, a relatively fast- changing set of actions depends on the tactics of the competition. The set of legal relationships that unite the actions of a boxer, which are gradually, formed in the course of the competition, into a single form the behavioral structure of the competition activity. 
In the process of the competition itself, the initially prepared for battle and the model of activity, of course, are clarified and adjusted according to the specific situations that arise in the competition.

This gives a special emotional tension to the athletes' behavior in the competition.

Competitive activity in boxing takes place in a non-standard environment, in conditions of time constraints, in situations where it is necessary to make decisions in response to unexpectedly changing situations. Here there is a direct struggle between the opponents, and the achievement of the result is represented by overcoming the active resistance of a particular opponent. In these cases, the boxer's activity consists of separate methods that are performed in a timely (rapid) manner, which allows to consider this activity in boxing as an example of operational activity.

Boxing skills in the work of the competition advantages and disadvantages of modern boxing will be displayed. But they are not easy to identify. This is due to the complexity of the fight, which consists of a large number of different actions performed at a very high rate.

Typically, boxing fights are divided into separate actions or combinations of them in episodes. They express special movement qualities and skills that reflect the physical and technical-tactical training of boxers. Such actions include, first and foremost, blows and defenses.

The purpose of the study was to determine the characteristics of the impact on young athletes by comparing the composition of technical and tactical actions used in training fights and official competitions in young boxers .
The aim of the research is training young boxers fighting, and the official acts of the tournament, their preparation and the use of tactical teams through optimization of individual amendments.

The class battles and competitions used to compare the contents of the technical and tactical actions a transfer of the results of the analysis of the correlation.

\section{RESEARCH METHODS}

Analysis of scientific and methodological literature, video analysis, questionnaire, theoretical analysis, statistical methods for determining the reliability of average sizes.

In the course of the research, we conducted pedagogical observations and recorded the use of young boxers in training fights and types of preparatory actions in competitions. More than 300 types of combat operations, including training battles and preparatory actions in competitions, were analyzed. A total of 60 tournament fights were recorded and analyzed.

\section{RESEARCH RESULTS}

Improvements in the basic types of movement in training and competitions in martial arts provide a technical and tactical advantage over the opponent.

In training and control battles, the tactical components of actions and their preparation and application are optimized, individual corrections are made.

Recommendations for quantitative types of enforcement actions to prepare, but they will not under any circumstances : during competitions or training o'tkazilayotganligiga serious struggle, depending on the 
characteristics ( Table 1 ). If the volume of application of deceptive shots ( Fintur ) $n$ ing competitions, up to $14.8 \%$ from $26.6 \%$ intrigues are reliable ( $p<0.05$ ), the legs and the body size of the actions carried out with the help of a lie significantly reduced ( $p<0$, respectively $05,48.8 \%$ to $40.0 \%$ ).

Uses statistical indicators and their efforts to prepare, first of all, to assess the reliability of the differences between the types of deceptive shots ( Fintur ) d parameters of the use of an outlet available .

According to the competitions and training janglaridagiga, there are almost twice as $\mathrm{N}$ Learn ( $p<0.05$ ). Athletes know that training to fight more freely and to that extent due to change hands with the dangerous movement and the distances you want attack, ignoring the need to prepare in order to implement it , o'yobga happy to put in production. As a result , competition is deceptive shots of large volumes of application, first of all , the boxers to fight the high levels of violence, and that the tactic ( which is above all the result of fights ) arising out of extreme caution (vigilance ) is explained.

Therefore, in preparation for the actions of another type, such as a relatively safe distance deceptive shots and the body with the help of false actions performed in the conditions of the competition - is characterized by large volumes $(\mathrm{P}<0.05)$.

A risk with the imitation of the preparatory actions ( strikes and shunting urge ) to carry out training battles and competition conditions ( Table 1 ) of the same size $(P>0.05)$.

Table 1.

Volumes of application of types of training fights and preparatory actions in competitions in young boxers

\begin{tabular}{|c|c|c|c|c|}
\hline \multirow{2}{*}{$\mathbf{t} / \mathbf{r}$} & \multirow{2}{*}{ Typesof protections } & \multicolumn{2}{|c|}{ Indicators of application of actions } & Reliabilityof differences \\
\cline { 3 - 5 } & Training battles & Battlesin competitions & \\
\hline 1. & $\begin{array}{c}\text { Deceitful blows } \\
\text { (tricks ) }\end{array}$ & 14.8 & 26.6 & $<0.01$ \\
\hline 2. & $\begin{array}{c}\text { And the actions of the } \\
\text { body lies }\end{array}$ & 48.8 & 40.0 & $<0.05$ \\
\hline 3. & Imitationof shocks & 20.4 & 22.1 & $>0.05$ \\
\hline 4. & Carryingout the maneuver & 9.8 & 8.2 & $>0.05$ \\
\hline 5. & Standing the different options & 6.2 & 3.1 & $<0.01$ \\
\hline
\end{tabular}

In turn, the use of close-up maneuvering and the imitation of strikes vary in numerical unreliability. However, it is necessary to recognize some aspects of the use of close maneuvering and specific to competitions in competitions, because due to the presence of 
certain risks such as misses, the competition requires a high level of attention, and imitation of blows lead to a clear assessment. For the same reasons, the volumes of selection of different options for standing in competitions decreased from $6.2 \%$ to $3.1 \%$ ( $p<0.01$ ) (Fig. 1), indicating a high aspiration for results in each episode of the fight.
By comparing the composition of the tools recorded in training battles and official competitions, it is important to determine the characteristics of the impact of the conditions of their implementation on the performance indicators (volumes and effectiveness) of the main types of offensive and defensive actions.
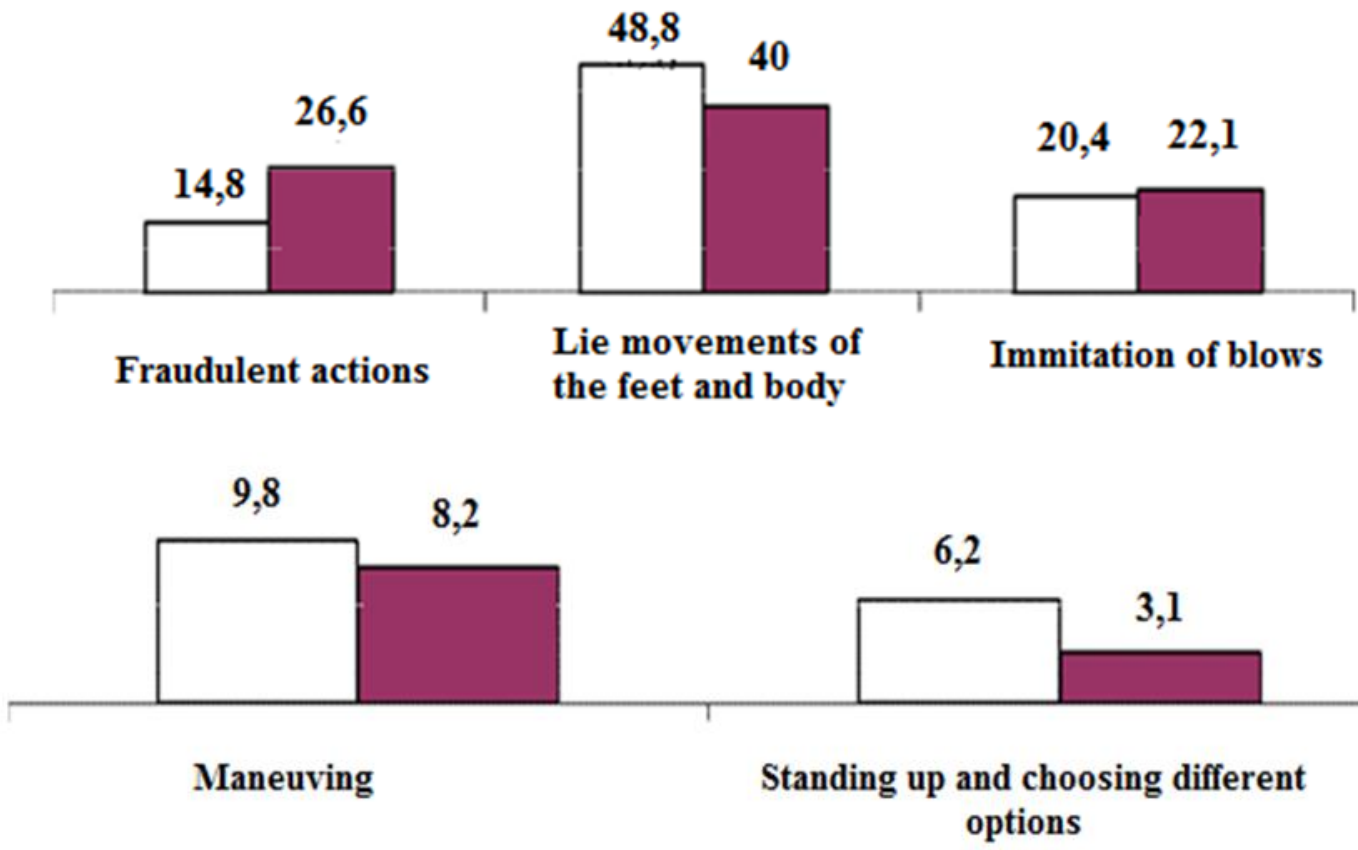

Figure 1. Volumes of application of types of training fights and preparatory actions in competitions in young boxers (\%)

The results of the correlation analysis revealed that (Table 2 ), the scope of attacks in training battles and competitions is closely related to each other $(r=0.91)$, while at the same time representing the superiority of attacks over other means of attack. In turn, there is only a weak correlation between response and the number of defenses $(r=0.57)$, which once again points to the problem of providing the necessary instantaneous spatial parameters that enable the implementation of means of resistance to these attacks in boxing. This is because the mistakes made by the defending athlete in ensuring a suitable distance before the start of combat operations create the conditions for the successful application of repetitive, sometimes even random, blows. 
Table 2 .

\section{Levels of interdependence between the scope of application of the main types of movement in training fights and competitions in young boxers}

\begin{tabular}{|c|c|c|c|c|c|c|}
\hline \multirow[b]{2}{*}{$t / r$} & \multirow[b]{2}{*}{$\begin{array}{c}\text { Actionsin training } \\
\text { battles }\end{array}$} & \multicolumn{5}{|c|}{ Actions in competitions } \\
\hline & & Attacks & $\begin{array}{l}\text { Protected signaled to } \\
\text { respond }\end{array}$ & $\begin{array}{l}\text { Counter- } \\
\text { attacks }\end{array}$ & $\begin{array}{l}\text { Counter- } \\
\text { attacks }\end{array}$ & $\begin{array}{c}\text { Anti- h } \\
\text { defense } \\
\text { s }\end{array}$ \\
\hline 1. & Attacks & 0.91 & -0.68 & 0.08 & -0.80 & -0.22 \\
\hline 2. & $\begin{array}{l}\text { To respond } \\
\text { to defense }\end{array}$ & & 0.57 & -0.75 & -0.15 & -0.19 \\
\hline 3. & Counter-attacks & & & 0.20 & 0.48 & 0.16 \\
\hline 4. & Counter blows & & & & 0.72 & 0.37 \\
\hline 5. & protection against & & & & & 0.80 \\
\hline
\end{tabular}

The data are reliable from $r=0.50$. The class battles and attacks against the fury of the competition between the volume of applications related $Q$ average level $(r=0.72)$. As for the attacks, correlation analysis shows there is no link between the volume of their application Q $(r=0.48)$. So, the training battles against attacks given the official competitions, training and conditions of use vary significantly. Exceptions are used to carry out attacks against the state and the diversity of high emotional intensity of fighting with the contraction of the opportunity to influence the result of blows to be explained.

Protection against the application of indicators each associated with an average density $q(r=$ 0.80 ), this response does not match the information on the application of defense . However, this correlation coefficient, it seems , not only to combat cross-dependencies between the vehicles, but the level of protection against the resistance as a means of enforcement responses to reflect the lower volumes .

The class battles and competitions related to the application of result correlation between the types of analysis, we need to recognize that the only attacks and counter- attacks that the average level associated with each other ( $r=0.8$, respectively 2 and $r=0,88)$. At the same time a reply to the defense and protection against the use of their result ( Table 3 ) does not correlate with each other ( $r$ $=0.09$ ), this is a reply to the defense of the complex is already known about the situation confirmed.

Unexpected situations that arise during the fight, extremely a result of the increased responsibility for the results and try to outshine the formation of a high level of mental winters 
were fighting to become the official competitions in accordance the opponent's attack with a decrease in resistance. First of all, the implementation of the defense have been reduced from will be displayed. Answer unclear circumstances in carrying out attacks against powerful opponents often performed with the resistance ( previous) may be attacks planned in advance. This resistance is not higher than the vehicle attacks result ( often less than $50 \%$ ). Their attacks against the conditions of application farqlangandagi result bo g Qlik reliable level of between $6(r=0.3)$ was not recognized. These shots boxers often random features. In turn, the attacks against the result between training and competition is weak correlation $(r=0.67)$, reflecting the effectiveness of the use of information related to attacks against tionship .

Levels of correlation between the effectiveness of the use of the main types of movement in training fights and competitions in boxers aged 14-15 years

\begin{tabular}{|c|c|c|c|c|c|c|}
\hline \multirow[b]{2}{*}{$t / r$} & \multirow[b]{2}{*}{$\begin{array}{c}\text { Actionsin training } b \\
\text { attles }\end{array}$} & \multicolumn{5}{|c|}{ Actionsin competitions } \\
\hline & & $\begin{array}{l}\text { Attac } \\
\text { ks }\end{array}$ & $\begin{array}{l}\text { Protected signaled to res } \\
\text { pond }\end{array}$ & $\begin{array}{c}\text { Counte } \\
\text { r-attac } \\
\text { ks }\end{array}$ & $\begin{array}{c}\text { Counte } \\
\text { r-attac } \\
\text { ks }\end{array}$ & $\begin{array}{l}\text { Anti- h d } \\
\text { efenses }\end{array}$ \\
\hline 1. & Attacks & 0.82 & -0.18 & 0.88 & -0.06 & 0.30 \\
\hline 2. & $\begin{array}{c}\text { To respondto defen } \\
\text { se }\end{array}$ & & 0.32 & -0.40 & -0.04 & 0.09 \\
\hline 3. & Counter- attacks & & & 0.67 & 0.50 & 0.03 \\
\hline 4. & Counter blows & & & & 0.39 & 0.36 \\
\hline 5. & protection against & & & & & 0.69 \\
\hline
\end{tabular}

Data are reliable starting from $r=0.50$. In evaluating the correlation associated qlilariga general, it should be the highest level of mutual dependency between the types of result indicators according to the volume of their application. This will confirm that the application of this or that action according to the situation emerging during combat tactical evaluation, on the basis of its well- known tayyorlanshini a means psixofiziologik is based on martial arts require a sufficient degree of specialization of functions. This conclusion, as well as the volume of application of the fights , training, competitions movements and the result confirms the absence of related tionship between them .

Tionship between livelihoods and closely identified a very small amount of process conditions of the main types of training methods to improve the technical and tactical formation, development, testing and teaching 
experience, as well as the need for action represents the application of scientific methods in order to analyze the contents of a duel.

\section{CONCLUSION}

Research has shown that boxers' use of shortrange maneuvers and imitation of blows varies in numbers. However, it is important to recognize some aspects of close maneuvering that are specific to competitions, as there are certain risks, such as missing a shot, that require a high level of attention, and imitation of blows can affect opponents' defensive reactions and goals. elps to make a clear assessment. For the same reasons, the volumes of choices for different standing positions in competitions decreased from $6.2 \%$ to $3.1 \%(P<0.01)$ (Figure 1), indicating a high degree of aspiration for results in each episode of the fight.

Q correlation analysis shows that there is no correlation between their application volumes $(r=0.48)$ ( Table 2 ). Thus, the instructions for the use of counter-attacks in training battles differ significantly from the conditions of their preparation and use in official competitions. The differences are explained by the variety of situations used to carry out counter-attacks and the narrowing of the ability to deliver result-oriented blows under the influence of the high emotional intensity of the battles.

\section{REFERENCES}

1. Achilov Muzafarov. , Xalmuxamedov R.D., Shin V.N, Tajibaev S.S., Rajabov G'.Q. Basics of training young boxers. - T. : Classic Word, 2012 . - 250 b.
2. Xalmuxamedov R.D. Boxing. Study guide. - T. : 2008, - 308 p

3. Shin V.N. Postroenie godichnogo tsikla podgotovki bokserov vysokoy kvalifikatsii: Dis... kand.ped.nauk . - T. : 2001. - 158 p.

4. Abdullaev F.T. Technical and tactical training of young boxers, taking into account the characteristics of competition and training activities. $D$ is. ped. fan. nom. - T. : 2009. -126 p .

5. Farkhod Turdalievich Abdullayev, Bahrom Pulatovich Pardayev The Role of Public Sports and Health Measures in Strengthening Children's Bodies Academic Research in Educational Sciences (ARES)

6. Abdullaeva B.P. Babaraximova B.P. Pardaev B.P.Using information and communication technologies in teaching process of various primary European Journal of Research and Reflection in Educational Sciences, 8 (10), 67-70. Progressive Academic Publishing, UK www.idpublications.org14.10.2020

7. Abdullaeva B.P. Abdullaeva F.T. Organization Of Swimming Lessons In Preschool Institutions THE AMERICAN JOURNAL OF SOCIAL SCIENCE AND EDUCATION INNOVATIONS. JULY 2020[ TAJSSEI]322ISSN (e):2689-100X DOI: https://doi.org/10.37547/tajssei/Volumeo2l ssue07-42

8. Abdullayeva, B. P., \& Babaraximova, B. P. (2020). MAKTABGACHA TA'LIM MUASSASASIDA FUTBOL DARSLARINI TASHKIL ETISH METODIKASI. Academic Research in Educational Sciences http://ares.uz/jurnallar-sahifasi/ares-vol-1no-3-2020

9. ACADEMICIA: An International Multidisciplinary Research Journal https://saarj.com ORGANIZATION AND 
METHODOLOGY OF CONDUCTING FOOTBALL LESSONS IN A PRESCHOOL INSTITUTION Abdullaeva B.P 650-655 10.5958/2249-7137.2021.00098.7

10. Abdullaeva В., Турдалиева M. Corruption in the field of education: assessments and ways to address "Тенденции и перспективи развития науки и образования в условиях глобализации".Международной научнопрактической интернет-конференции. г.Переяслав, Украина.2020 год 30 апреля.58.

11. Abdullayev F.T. Abdullayeva B.P. Maktabgacha va kichik maktab yoshidagi bolalarning jismoniy rivojlanishida jismoniy mashqlarning o‘rni. 2021 2-son (Maxsus) "XALQ TA'LIMI" ilmiy-metodik jurnali. 2021. № 1. www.xtjurnali.zn.uz

12. Абдуллаева, Б. П. (2021). МАКТАБГАЧА ТАЪЛИМ ТАШКИЛОТЛАРИ ВА БОШЛАНҒИЧ СИНФЛАРАА ЖИСМОНИЙ ТАРБИЯ МАШҒУЛОТЛАРИНИ ТАШКИЛ ҚИЛИШ. ACADEMIC RESEARCH IN EDUCATIONAL SCIENCES, 2(3), 1324-1333. DOI: $\quad 10.24411 / 2181-1385-2021-$ 00545http://ares.uz/storage/app/media/2 021/Vol_2_No_3/1324-1333.pdf 